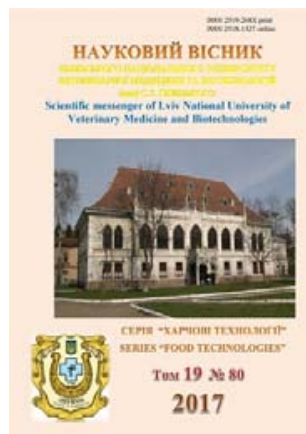

Науковий вісник Львівського національного університету ветеринарної медицини та біотехнологій імені С.3. Гжицького

Scientific Messenger of Lviv National University of Veterinary Medicine and Biotechnologies

doi:10.15421/nvlvet8022

ISSN 2519-268X print

ISSN 2518-1327 online

$\underline{\text { http://nvlvet.com.ua/ }}$

УДК 637.14/.34

\title{
Аналіз основних рослинних джерел біофлавоноїдів для створення продуктів лікувально-профілактичного призначення
}

\author{
О.П. Сухорська, Н.Б. Сливка, О.Я. Білик \\ olgaps@ukr.net, slyvkanat@ukr.net, bilyk_oksi@ukr.net
}

Львівський національний університет ветеринарної медицини та біотехнологій імені С.3. Гжицького, вул. Пекарська, 50, Львів, 79010, Україна

Проблеми захисту і корекиії дизрегуляиії організму і його основних систем при радіаційному навантаженні можуть бути ефективно вирішені шляхом введення в організм дієтичних харчових добавок з біологічною активністю та функціональних продуктів харчування. У радіозахисному харчуванні важливе значення відводиться флавоноїдам. Метою досліджень було проведення аналізу основних рослинних джерел біофлавоноїдів та розробка харчової композичї для продуктів лікувально-профілактичного призначення, зокрема йогуртів.

Для приготування фітокомпозииї обрано ягоди шипшини, аронії та смородини чорної. Фітокомпозичії вносили у вигляді пюре. Для подовження терміну зберігання та використання композииії у зимовий період ї̈ пастеризують 25 хв при температурі $85^{\circ} \mathrm{C}$. Кількісне співвідношення у пюре ягід смородини, аронії та шипиини становить 3:4:3.

Йогурт виготовляли термостатним способом. Для заквашування використовували закваску АВY-3 компанї Chr.Hansen, до складу якої входять такі види культур мікроорганізмів як Bifidobacterium species, Streptococcus thermophilus, Lactobacillus acidophilus, Lactobacillus delbrueckii subsp. bulgaricus.

Розроблено речептури кисломолочних напоїв із використанням харчової композичії. Масова частка жиру в готовому продукті становить 2,5\%. Досліджено основні фізико-хімічні показники готових продуктів. Встановлено, щчо збільщення сухих речовин суміші сприяє зростанню кількості міжмолекулярних просторових зв'язків між частинками казеїну, щэо призводить до інтенсивнішої їх взаємодії. Унаслідок иьього помітно збільшується в 'язкість продукту і знижується ступінь синерезису під час зберігання.

Запропонована технологія йогурту з наповнювачами радіозахисної дії дозволяє розширити асортимент продукиї з радіозахисними властивостями та забезпечити населення України, зокрема працівників зони відчуження та осіб, які проживають на екологічно забрудненій території, оздоровчими продуктами харчування.

Ключові слова: біофлавоноїди, аронія, чорна смородина, иипшина, радіопротектори, йогурт, технологія, органолептичні показники.

\section{Анализ основных растительных источники биофлавоноидов для создания продуктов лечебно-профилактического назначения}

О.П. Сухорская, Н.Б. Сливка, О.Я. Билык

olgaps@ukr.net, slyvkanat@ukr.net, bilyk_oksi@ukr.net

Львовский наџиональный университет ветеринарной медицины и биотехнологий имени С.3. Гжиџкого, ул. Пекарская, 50, г. Львов, 79010, Украина

Проблемы защиты и коррекции дизрегуляции организма и его основных систем при радиационной нагрузке может быть эффективно решены путем введения в организм диетических пищевых добавок с биологической активностью и функциональных продуктов питания. В радиозащитном питании важное значение отводится флавоноидам. Целью исследований было проведение анализа основных растительных источников биофлавоноидов и разработка пищевой композиции для продуктов лечебно-профилактического назначения, в частности йогуртов.

\section{Citation:}

Sukhorska, O.P., Slyvka, N.B., Bilyk, O.Ya. (2017). Analysis of main sources of bioflavonoids the creation of products of medical and prophylactic appointment. Scientific Messenger LNUVMB, 19(80), 107-110. 
Для приготовления фитокомпозиции избраны ягоды шиповника, аронии и смородины черной. Фитокомпозиции вносили в виде пюре. Для продления срока хранения и использования композиции в зимний период пастеризуют 25 мин. при температуре $85^{\circ} \mathrm{C}$. Количественное соотношение в пюре ягод смородинь, аронии и шиповника составляет 3:4:3.

Йогурт изготавливали термостатным способом. Для сквашивания использовали закваску АВY-3 компании Сһr.Напsеп, в состав которой входят такие виды культур микроорганизмов как Bifidobacterium species, Streptococcus thermophilus, Lactobacillus acidophilus, Lactobacillus delbrueckii subsp. bulgaricus.

Разработаны рецептуры кисломолочных напитков с использованием пищевой композиции. Массовая доля жира в готовом продукте составляет 2,5\%. Исследованы основные физико-химические показатели готовых продуктов. Установлено, что увеличение сухих веществ смеси способствует росту числа межмолекулярных пространственных связей между частицами казеина, что приводит к интенсивному их взаимодействию. В результате заметно увеличивается вязкость продукта и снижается степень синерезиса при хранении.

Ключевые слова: биофлавоноиды, арония, черная смородина, ииповник, радиопротекторы, йогурт, технология, органолептические показатели.

\title{
Analysis of main sources of bioflavonoids the creation of products of medical and prophylactic appointment
}

\author{
O.P. Sukhorska, N.B. Slyvka, O.Ya. Bilyk \\ olgaps@ukr.net, slyvkanat@ukr.net, bilyk_oksi@ukr.net
}

\begin{abstract}
Stepan Gzhytskyi National University of Veterinary Medicine and Biotechnologies Lviv, Pekarska Str., 50, Lviv, 79010, Ukraine
\end{abstract}

Problems of protection and correction of the body deregulation and its main systems at radiation exposure can be effectively resolved by administration of the dietary food supplements with biological activity as well as functional foodstuffs. Flavonoids play important role in radio protective nutrition. The aim of the research was to analyze the main plant sources of bioflavonoids and developing food composition for food with prophylactic and treatment purposes, including yogurt.

To prepare fitocomposition such berries as hips, chokeberry and black currant were selected. Fitocompositions were introduced in the form of puree. To prolong storage and use of the compositions in winter period it is pasteurized for 25 minutes at $t 85^{\circ} \mathrm{C}$. The proportion of mashed currant, chokeberry and hips is 3:4:3.

Yogurt is made by thermostatic means. For fermentation the ferment ABY 3 of Chr.Hansen Company was used, which includes the following types of microbial cultures Bifidobacterium species, Streptococcus thermophilus, Lactobacillus acidophilus, Lactobacillus delbrueckii subsp. bulgaricus.

Dairy beverage recipes have been developed using the food composition. Fat content in the finished product is $2.5 \%$. The basic physical and chemical properties of finished products have been researched. It was established that increasing of solid mixtures contributes to the number of dimensional intermolecular ties among the particles of casein, resulting in their enhanced interaction. As a result, the viscosity of the product significantly increases and the degree of syneresis reduces during its storage.

The proposed yoghurt technology with fillers of radioprotective action allows extending the range of products with radioprotective properties and providing the population of Ukraine, including the exclusion zone workers and people living in polluted area with wellness food.

Key words: bioflavonoids, chokeberry, black currant, hips, radioprotectors, yogurt, technology, organoleptic properties.

\section{Вступ}

Останнім часом перед людством гостро стоїть проблема якості їжі. Якісний склад продуктів харчування на початку третього тисячоліття значною мірою пов'язаний $з$ різким погіршенням екологічної ситуації в усьому світі, яке обумовлене інтенсивними викидами у навколишнє середовище продуктів техногенної діяльності людини. В Україні екологічний стан поглиблюється аварією на ЧАЕС, наслідки якої сьогодні відчутні практично на всій території країни (Bakulina and Bljuz, 2005; Hnyk, 2011).

При тривалому проживанні на забруднених територіях доза опромінення організму людини формується за рахунок зовнішнього опромінення радіонуклідами, які випали на поверхню грунту, а також внутрішнього - через пероральне надходження радіонуклідів до організму 3 продуктами харчування і водою. Внаслідок останнього сумарне дозове навантаження сьогодні досить суттєве і сягає від 30 до 50\% (Peresichnyi et al., 2008).
Уникнути надходження радіонуклідів до організму людини практично неможливо, але не дати їм затриматися в організмі, нейтралізувати їхню дію можна за допомогою біофлавоноїдів, сапонінів, пектинів, якими багаті рослини. Серед судинних (вищих) рослин природної флори України є такі, введення яких в організм перед або під час дії іонізуючих випромінювань підвищує радіо стимуляцію. Це рослини, які умовно можна назвати «радіопротектори» - захисники у харчовому раціоні людей, які проживають на забруднених радіонуклідами територіях. Саме ці рослини здатні підтримувати імунну систему, яка стає досить ослабленою під впливом радіації, а також захищати мембрани клітин від випромінення, зв'язувати радіонукліди і виводити їх 3 організму (Kudrjashhova, 2005).

Особливо велике значення для захисту організму людини від радіації мають такі рослини, як перстач прямостоячий (в народі його називають калган), буквениця лікарська (хвощ польовий), буркун лікарський, гірчак звичайний (спориш). Антирадіаційні та антисептичні властивості має листя чорниці, медунки, 
звіробою, материнки звичайної та чебрецю повзучого. Також досить сильні антирадіаційні властивості мають плоди і ягоди, зокрема багатьох дикоростучих рослин: бузини чорної, горобини, груші звичайної (дички), журавлини болотної, калини, шипшини, ожини, смородини чорної, чорниці (Makov, 2000).

Для підбору рослин, багатих на флавоноїди, ми скористались спеціальною літературою і обрали ягоди шипшини, аронії та смородини чорної.

Літературні дані свідчать про те, що біофлавоноїди шипшини представлені катехінами, лейкоантоціанами, фенолкислотами, антоціанами, флавонолами. Кожна із цих сполук має певну мембраностабілізуючу активність і запобігає накопиченню радіонуклідів в організмі людини.

Вміст лейкоантоціанів та катехінів у більшості сортів шипшини значно вищий, ніж інших Р-активних сполук, що зумовлює значну біологічну активність їх плодів. Так, вміст катехінів коливається від 856 до 2712 мг\%, а лейкоантоціанів - у межах від 72 до 1696 мг\%. Сумарний вміст катехінів та лейкоантоціанів корелює для всіх різних сортів шипшини з сумарною кількістю дубильних та барвних речовин, які також здатні зв'язувати і виводити з організму людини різні за структурою ксенобіотики.

Відомо, що шипшина $є$ основною сировиною для отримання аскорбінової кислоти. Ї̈̈ вміст у різних сортах теж коливається у досить широких межах - від 205 до 3100 мг\%. Важливою характеристикою ягід шипшини $є$ і наявність в них значної кількості органічних кислот. Загальна кислотність плодів складає $1,11 \ldots 4.83 \%$. За якісним вмістом домінують яблучна, хлорогенова, хінна, бурштинова, фумарова кислоти.

Наявність в ягодах шипшини пектинових речовин дає можливість також прогнозувати високі радіозахисні властивості створюваної фітокомпозиції, оскільки пектини $є$ і стабілізаторами аскорбінової кислоти, і ефективною протиотрутою стосовно важких металів та інших токсичних сполук.

Стосовно аронії чорноплідної цікавою $є$ інформація, що як сировина для отримання харчового барвника, якого гостро потребує харчова промисловість, ця культура є незамінною. Загальна кількість дубильних і барвних речовин у зрілих плодах аронії в лісостепах України складає 1210...1660 мг\%, деякі сорти аронії містять до 4000 мг\% речовин Р-вітамінної активності. У зрілих плодах аронії міститься до 0,6\% пектину та близько 1\% протопектину. Стосовно вмісту органічних кислот, то тут перелік теж досить широкий сорбінова, хлорогенова, лимонна, яблучна, кавова, хінна, бурштинова. Вміст аскорбінової кислоти в ягодах цієї культури коливається від 15 мг\% до $280 \mathrm{мг} \%$.

Ягоди смородини чорної приваблюють високим співвідношенням аскорбінової кислоти і біофлавоноїдів (520..800 мг\% : 780...1450 мг\%), пектинових речовин, мікро- і макроелементів (Makov, 2000; Kapreliants and Iorhachova, 2003; Iakubenko et al., 2009).
Метою нашої роботи було проведення аналізу основних рослинних джерел біофлавоноїдів, розробка технології йогуртів із використанням рослинної композиції з радіопротекторними властивостями.

\section{Матеріал і методи досліджень}

Досліди проводились в умовах наукових лабораторій кафедр екології та біології і технології молока i молочних продуктів Львівського національного університету ветеринарної медицини та біотехнології імені С. 3. Гжицького

Йогурт виготовляли термостатним способом. Для заквашування використовували закваску АВY-3 компанії Chr. Hansen, до складу якої входять такі види культур мікроорганізмів, як Bifidobacterium species, Streptococcus thermophilus, Lactobacillus acidophilus, Lactobacillus delbrueckii subsp. bulgaricus.

Фітокомпозиції вносили у вигляді пюре. Пюре із аронії чорноплідної та смородини отримують такимчином: ягоди аронії та смородини відділяють від плодоніжок. Для зменшення гіркоти витримують декілька днів в морозильній камері або прогрівають у духовій шафі протягом 1-1,5 год. при температурі 115-120 ${ }^{\circ} \mathrm{C}$. Підготовлені ягоди протирають через сито. Для приготування пюре із шипшини ягоди миють, заливають водою і проварюють 15 хв. Потім видаляють кісточки, протирають через сито. Підготовлені складники змішують.

Для подовження терміну зберігання та використання композиції у зимовий період іiі консервують. Для цього суміш накладають у банки, які пастеризують 25 хв при температурі $85{ }^{\circ} \mathrm{C}$. Термін зберігання такої композиції 12 місяців.

Було проведено 4 дослідні виробітки кисломолочного напою із таким співвідношенням молочної основи і харчової рослинної композиції, \%:

Варіант 1 - 100 (контроль)

Варіант 2-90:10

Варіант 3-85:15

Варіант $4-80: 20$

\section{Результати та їх обговорення}

Лікарські рослини, що входять до складу запропонованих фітокомпозицій, взаємно доповнюють одна одну, посилюють дію біологічно активних речовин, що входять до їхнього складу. Вони здійснюють антиоксидантну, радіопротекторну, імуномодулюючу, капілярозміцнюючу та мембраностабілізуючу дії на організм людини, що свідчить про перспективність обраних для фітокомпозиції складових для використання у технології йогуртів для радіозахисного харчування.

Проте важливим було визначити співвідношення рецептурних компонентів харчової композиції із заданими властивостями. Для цього було створено ряд експериментальних продуктів, які представляли дегустаційній комісії (табл. 1). 
Кількісне співвідношення складників харчової композиції з радіозахисними властивостями

\begin{tabular}{|l|c|c|c|}
\hline \multicolumn{1}{|c|}{ Складники } & Композиція 1 & Композиція 2 & Композиція 3 \\
\hline Ягоди шипшини, \% & 50 & 35 & 30 \\
\hline Ягоди аронії, \% & 10 & 25 & 40 \\
\hline Ягоди смородини, \% & 40 & 40 & 30 \\
\hline
\end{tabular}

Перша спроба виявилася найменш вдалою тому, що за основу ми взяли ягоди шипшини та листя смородини у кількості 50\% і лише $10 \%$ ягід аронії. При органолептичному дослідженні цих продуктів очікуваних результатів ми не отримали, тому що смак був терпким, з гіркотою, що негативно позначилося б на виготовленому продукті.

В подальшому ми спрямовували свої дослідження на збільшення частки ягід аронії та зменшення шипшини. В результаті дегустації було встановлено, що це сприяє поліпшенню смакових та ароматичних якостей продукту.

Виходячи 3 оцінок дегустаційних аналізів, кінцевим результатом стало створення харчової композиції № 3, органолептичні показники якої були найкращими.

Розроблення рецептур йогуртів здійснювали, розраховуючи жировий баланс продукту. Масова частка жиру в готовому продукті становить 2,5\%.

Рецептури йогурту з наповнювачами наведено в табл. 2.

Таблиия 2

Рецептури йогуртів 3 наповнювачами

\begin{tabular}{|l|c|c|c|c|}
\hline \multirow{2}{*}{ Компоненти } & \multicolumn{3}{|c|}{ Маса компонентів } & Дослід 2 \\
\cline { 2 - 5 } & Контроль & Дослід 1 & 797,5 & 747,5 \\
\hline Молочна основа & 950,0 & 847,5 & 50.0 & 50.0 \\
\hline Цукор & 50,0 & 50,0 & 150,0 & 200,0 \\
\hline Харчова композиція & - & 100,0 & 2,5 & 2,5 \\
\hline Регулятор кислотності & - & 2,5 & 1000 & 1000 \\
\hline Всього & 1000 & 1000 & \\
\hline
\end{tabular}

При оцінці смакових переваг молочного продукту 3 частковою заміною молочної сировини наповнювачами рослинного походження радіопротекторної дії було встановлено, що продукт має гарне смакове поєднання компонентів.

На консистенції кисломолочних гелів суттєво позначається вміст у молочній основі сухих речовин рослинної сировини, а саме пюре із ягід глоду, шипшини та аронії. Збільшення сухих речовин суміші сприяє зростанню кількості міжмолекулярних просторових зв'язків між частинками казеїну, що призводить до інтенсивнішої їх взаємодії. Унаслідок цього помітно збільшується в'язкість продукту і знижується ступінь синерезису під час зберігання

\section{Висновки}

Отже, запропонована технологія йогурту з наповнювачами радіозахисної дії дозволяє розширити асортимент продукції з радіозахисними властивостями. Ці продукти задовольняють добову потребу організму в нутрієнтах радіозахисної дії на 15-20\%.

Соціальний ефект від упровадження новітньої продукції полягає в забезпеченні населення України, зокрема працівників зони відчуження та осіб, які проживають на екологічно забрудненій території, оздоровчими продуктами харчування.

\section{Бібліографічні посилання}

Bakulina, O.N., Bljuz, O.V. (2005). Funkcional'nye ingredienty dlja voploshhenija Koncepcii zdorovogo pi- tanija. Pishhevye ingredienty. Syr'e i dobavki . 2, 3032 (in Russian).

Hnyk, D.H. (2011). Zakhysni vlastyvosti produktiv. K.: Vyshcha shkola (in Ukrainian).

Kapreliants, L.V., Iorhachova, K.H. (2003). Funktsionalni produkty. Odesa: Druk (in Ukrainian).

Kudrjashhova, A.A. (2005). Novye napravlenija nauchnotehnicheskogo razvitija $\mathrm{v}$ oblasti pitanija, zdorov'ja i jekologii. Pishhevaja promyshlennost'. 9, 110-113 (in Russian).

Makov, R.H. (2000). Khimichnyi sklad ovochiv, fruktiv, nasinnia. M: DeLyprynt (in Ukrainian).

Peresichnyi, M.I. Kravchenko, M.F., Fedorova, D.V. (2008). Tekhnolohiia produktiv kharchuvannia funktsionalnoho pryznachennia. K.: Kyiv. nats. torh.ekon. un-t (in Ukrainian).

Rudavska, H.B., Tyshchenko, Ye.V., Prytulska, N.V. (2002). Naukovi pidkhody ta pryktychni aspekty optymizatsii asortymentu produktiv spetsialnoho pryznachennia: Monohrafiia. K.: Kyiv (in Ukrainian).

Iakubenko, B.Ie., Hryhoriuk, I.P., Melnychuk, M.D. (2009). Likarske roslynnytstvo: stan ta perspektyvy vidrodzhennia. Materialy mizh nar. nauk.-prakt. konf. do 200-richchia Nikitskoho botanichnoho sadu: «Introduktsiia i selektsiia aromatychnykh ta likarskykh roslyn». Yalta, 227-228 (in Ukrainian).

Received 22.09.2017

Received in revised form 25.10.2017 Accepted 27.10.2017 